\title{
Prioritas Penghuni Terkait Perawatan Rumah Susun Sederhana Sewa di Surabaya
}

\author{
Tenant's Maintenances Priority in Simple Flat Surabaya
}

\author{
Edward Gondo Kusuma ${ }^{1}$, dan Njo Anastasia ${ }^{2}$
}

Diterima: 5 Agustus 2020 Disetujui: 15 September 2020

\begin{abstract}
Abstrak: Penelitian sebelumnya fokus pada kondisi, kesadaran, dan prioritas penghuni terhadap perawatan properti pada perumahan dan rusun kelas menengah sehingga rumah susun sederhana sewa (rusunawa) belum mendapatkan perhatian khusus terkait masalah perawatan properti. Penelitian ini bertujuan untuk mengetahui prioritas perawatan yang diutamakan, alasan yang diberikan oleh penghuni untuk dilakukannya perawatan rusunawa, mengetahui korelasi antara prioritas perawatan dan alasan dilakukannya perawatan. Metode yang digunakan adalah survei dengan penyebaran kuesioner. Perawatan properti terbagi menjadi tiga, yaitu struktur, arsitektur, dan utilitas. Hasil dari penelitian ini menunjukkan bahwa masingmasing penghuni rusunawa memiliki prioritas perawatan dan alasan dilakukan perawatan yang berbeda-beda. Perbedaan pendapat terjadi pada masing-masing penghuni rusunawa, di mana beberapa penghuni rusunawa lebih mementingkan perawatan dan alasan dilakukan perawatan utilitas daripada perawatan struktur dan arsitektur. Semakin penting suatu perawatan, maka semakin kuat alasan untuk dilakukannya perawatan tersebut. Penelitian ini memberikan manfaat pada pengelola rusunawa yaitu Pemkot Surabaya untuk menyusun prosedur yang dapat diajukan penghuni untuk memperoleh perawatan pada rusunawa yang mengalami kerusakan sesuai dengan prioritas kebutuhan penghuni. Pihak pengelola juga dapat menyusun strategi perawatan sebelum dan sesudah terjadi kerusakan.
\end{abstract}

Kata kunci: prioritas perawatan, alasan dilakukan perawatan, rumah susun sederhana sewa

\begin{abstract}
Previous research focused on the conditions, awareness, and priorities of tenants for property maintenance in housing and middle-class flats, so that simple flats have not received special attention related to property maintenance issues. This study aims to determine the maintenance priority, the reasons given by tenants to maintain simple flat, the correlation between maintenance priorities and the reasons for maintain. The method used was a survey by distributing questionnaires. Property maintenance is divided into three such as structure, architecture and utility. The results show that each tenant has different priorities on property maintenance and their reasoning behind it. Disagreements occur in each of the tenants, where some of them are more concerned with maintenance and reasons for utility maintenance rather than structure and architecture maintenance. The more important the maintenance is, the stronger reason to do the maintenance. This research provides benefit to the management, namely the Surabaya City Governement, to develop procedures that can be proposed by tenants to obtain maintenance for damaged flat in accordance with priority
\end{abstract}

\footnotetext{
1 Fakultas Teknik Sipil dan Perencanaan, Universitas Kristen Petra, Surabaya

2 Program Managemen Keuangan dan Investasi, Fakultas Bisnis dan Ekonomi, Universitas Kristen Petra, Surabaya
}

Korespondensi: edwardgondokusuma@gmail.com; anas@petra.ac.id 
needs of tenants. The managers can also develop maintenance strategies before and after damaged occur.

Keywords: maintenance priority, the reason for maintenance, simple flat

\section{PENDAHULUAN}

Pembangunan rumah susun sederhana sewa (rusunawa) adalah salah satu cara pemerintah untuk memecahkan masalah kebutuhan tempat tinggal pada lokasi yang padat, terutama pada daerah perkotaan yang jumlah penduduknya selalu meningkat, khususnya Surabaya. Menurut UU No 20 Tahun 2011 tentang Rumah Susun, rumah susun adalah bangunan gedung bertingkat yang dibangun dalam suatu lingkungan yang terbagi dalam bagian-bagian yang distrukturkan secara fungsional, baik dalam arah horizontal maupun vertikal dan merupakan satuan-satuan yang masing-masing dapat dimiliki dan digunakan secara terpisah, terutama untuk tempat hunian yang dilengkapi dengan bagian bersama, benda bersama, dan tanah bersama (Menteri Hukum dan Hak Asasi Manusia, 2011). Tujuan pengelolaan rusunawa sendiri menurut Peraturan Menteri Negara Perumahan Rakyat nomor 14/PERMEN/M/2007 tentang pengelolaan rusunawa bab II pasal 2 adalah agar pengelolaan rusunawa dapat berhasil dan berdaya guna sehingga dapat mencapai pemenuhan rumah tinggal yang terjangkau, bermartabat, nyaman, aman, dan sehat bagi penghuninya. Berdasarkan sasaran kelompoknya, rumah susun sederhana milik pemerintah dikategorikan dalam dua jenis, yaitu rumah susun sederhana untuk dimiliki atau rusunami, dan rumah susun sederhana sewa atau rusunawa. Rusunawa pun dibagi dalam dua kategori yaitu dengan subsidi dan tanpa subsidi (Kementerian Negara Perumahan Rakyat, Peraturan Menteri Negara Perumahan Rakyat Nomor 18 Tahun 2007 tentang Petunjuk Pelaksanaan Perhitungan Tarif Sewa Rumah Susun Sederhana Sewa yang dibiayai oleh APBN dan APBD, 2007). Pemerintah Provinsi Jawa Timur menyediakan rusunawa dengan subsidi penuh yang diprioritaskan bagi kelompok dengan kemampuan ekonomi yang sangat terbatas, hanya dapat membayar sewa untuk menutup biaya operasional saja. Menurut Pemerintah Kota Surabaya (2012), menunjukkan bahwa pada tahun 2012, Surabaya memenangkan lomba pengelolaan rusunawa tingkat provinsi Jawa Timur. Namun setelah tahun 2012, Surabaya tidak lagi memenangkan lomba pengelolaan rusunawa tingkat provinsi Jawa Timur. Hal ini memungkinkan adanya dampak perawatan pada pengelolaan rusunawa di Surabaya. Berdasarkan wawancara pribadi dengan ibu Siti sebagai penghuni rusunawa Menanggal, pada tanggal 29 Oktober 2019, hari Selasa pukul 16.22 WIB, berpendapat bahwa penundaan tindakan perawatan dipengaruhi oleh keterbatasan dana atau anggaran dari pemerintah.

Dalam Peraturan Menteri Negara Perumahan Rakyat Nomor 14/PERMEN/M/2007 tentang Pengelolaan Rumah Susun Sederhana Sewa,dan Peraturan Menteri Pekerjaan Umum Nomor 24/PRT/M/2008 tentang Pedoman Pemeliharaan dan Perawatan Bangunan Gedung mengartikan perawatan sebagai kegiatan memperbaiki dan/atau mengganti bagian bangunan gedung, komponen, bahan bangunan dan/atau prasarana dan sarana agar bangunan gedung tetap layak fungsi (Kementerian Negara Perumahan Rakyat, 2007). FloresColen, Brito \& Freitas (2010) berpendapat, karena keterbatasan dana, tindakan perawatan harus dapat diandalkan dan ekonomis. Prioritas perawatan sendiri didasari oleh keseimbangan antara penyelesaian perawatan dan tujuan rencana perawatan (Wing, Mohammed, \& Abdullah, 2016a). Prioritas perawatan dilakukan untuk meminimukan biaya perawatan, memaksimumkan performa atau kualitas bangunan dan meminimumkan resiko kerusakan pada bangunan (Wing, Mohammed, \& Abdullah, 2016b). Prioritas perawatan terdapat pada tampilan bangunan atau façade (Flores-Colen, Brito, \& Freitas, 2010). Prioritas perawatan yang mendesak apabila terjadi kerusakan struktur dan memerlukan tindakan perawatan segera (Suffian, 2013; Usman \& Winandi, 2009). 
Keterlibatan warga dalam tindakan perawatan akan meningkatkan transparansi dalam mengenali prioritas perawatan dan meningkatkan kesadaran akan perawatan, dengan demikian, meningkatkan kualitas bangunan (Shen, Lo, \& Wang, 1998). Menurut Mossel \& Jansen (2010), kurangnya kesadaran penghuni mengakibatkan adanya kerusakan yang tidak dilaporkan sehingga memperburuk kondisi bangunan di kemudian hari dan membawa pengaruh buruk bagi kehidupan penghuni. Kesadaran akan alasan dilakukan tindakan perawatan sebagai prioritas utama diberikan penghuni bangunan di Nigeria adalah menjaga kelayakan bangunan (Oladapo, 2006). Kangwa dan Olubodun (2003) mengatakan, bahwa keikut sertaan penghuni atau pemilik dalam tindakan perawatan berpengaruh signifikan terhadap kesuksesan tindakan perawatan. Pada suatu perumahan, penghuni biasanya secara sukarela terlibat atau mengabaikan pentingnya keterlibatan terkait pemeliharaan gedung (Yau, 2011).

Setiap bangunan tempat tinggal akan berhadapan dengan masalah kerusakan pada bangunan yang tidak dapat dihindari akibat efek penggunaan (Ozdemir, 2002). Kerusakan pada bangunan ini dibagi menjadi tiga yaitu kerusakan struktur, arsitektur dan utilitas (Usman \& Winandi, 2009). Untuk memperpanjang umur bangunan, sangat penting untuk memiliki perawatan yang tepat sehingga semua efek buruk yang terjadi pada bangunan dapat dikurangi atau dihilangkan (Chew, Tan, \& Kang, 2004). Menurut Stewart (2003), kurangnya kesadaran penghuni tentang pekerjaan perawatan akan berdampak penting pada keadaan dan kondisi kehidupan penghuni yang buruk. Penelitian di Jakarta menampilkan penghuni sadar akan pentingnya perawatan properti namun tidak melakukan tindakan perawatan (Arumsari \& Rarasati, 2017). Penelitian Yusof, Abdullah, Zubedy \& Najib (2012) menyatakan adanya hubungan signifikan positif antara prioritas perawatan dan alasan dilakukan perawataan dengan menggunakan metode korelasi. Hal ini menunjukkan penghuni memerlukan pengetahuan perawatan dasar, khususnya untuk mendeteksi masalah perawatan dan memberi tahu manajemen pengelola untuk mengambil tindakan yang tepat. Prioritas perawatan dilakukan untuk mengelola dana supaya optimal melakukan tindakan perawatan. Maka dari itu, penelitian ini dilakukan untuk mengetahui korelasi antara priotitas penghuni dengan alasan penghuni terkait kebutuhan perawatan.

\section{METODE}

Jenis penelitian yang digunakan pada penelitian ini adalah asosiatif kuantitatif. Penelitian ini dikatakan asosiatif karena penelitian ini menguji perbandingan korelasi atau hubungan antara dua variabel, dikatakan kuantitatif karena penelitian ini berupa angka-angka dan analisisnya menggunakan statistik (Sugiyono, 2017). Penelitian ini untuk mengetahui hubungan korelasi antara preferensi prioritas perawatan dan alasan dilakukannya perawatan pada penghuni rumah susun sederhana sewa (rusunawa) di Surabaya. Teknik samplingyang digunakan adalah purposive sampling, dimana responden adalah penghuni yang tinggal di rusunawa Surabaya lebih dari dua tahun dan umur bangunan rusunawa yang dihuni lebih dari tiga tahun. Teknik pengumpulan data primer melalui penyebaran kuesioner. Sebelumnya dilakukan permohonan ijin terlebih dahulu pada pihak Pemkot Surabaya melalui penyerahan surat permohonan penelitian ke Badan Kesatuan Bangsa Politik dan Perlindungan Masyarakat (BangKesBangPol) dan di salurkan ke Dinas Pengelolaan Bangunan dan Tanah (DPBT) untuk mendapatkan surat ijin penelitian pada rusunawa. Perolehan data melalui wawancara dan sebar kuesioner print-out yang ditujukan langsung kepada penghuni rusunawa Jambangan, Menanggal, Grudo, Penjaringan Sari III dan Siwalankerto. Kuesioner berisi pertanyaan atau pernyataan tertulis terkait perawatan yang diukur menggunakan Skala Likert dari skala 1 (sangat tidak penting) sampai dengan skala 6 (sangat penting). Pre-test kuesioner diuji coba pada orang awam dan kalangan tertentu terlebih dahulu sebelum penyebaran terhadap penghuni rusunawa. Setelah data diperoleh 
maka dilakukan proses pemberian kode, dan uji statistik yaitu analisis deskriptif, uji validitas, uji reliabilitas untuk pengecekan kesahihan data dari kuesioner serta mengeliminasi datadata yang tidak sesuai dengan kriteria responden. Untuk menjawab hipotesa dilakukan analisis rangking terhadap atribut-atribut yang diteliti, uji beda untuk mengetahui perbedaan preferensi antara penghuni rusunawa, serta uji korelasi Pearson untuk membuktikan korelasi antara masing-masing perawatan dan alasan dilakukan perawatan.

\section{HASIL PENELITIAN}

\section{Gambaran Umum Penelitian}

Responden terdiri dari penghuni rumah susun sederhana sewa yang dikelola oleh Pemkot Surabaya. Rumah susun sederhana sewa (rusunawa) yang teliti adalah rusunawa Jambangan, Menanggal, Grudo, Penjaringan Sari III dan Siwalankerto. Berdasarkan pengumpulan data yang dilakukan, didapat jumlah responden sebanyak 210 orang. Adapun deskripsi demografi penghuni rusunawa dapat dilihat pada Tabel 1 dan dekripsi kondisi sewa penghuni dapat dilihat pada Tabel 2.

Tabel 1. Dekripsi demografi penghuni rusunawa

\begin{tabular}{|c|c|c|c|c|c|c|}
\hline Informasi & $\begin{array}{l}\text { Rusunawa } \\
\text { Jambangan }\end{array}$ & $\begin{array}{l}\text { Rusunawa } \\
\text { Menanggal }\end{array}$ & $\begin{array}{c}\text { Rusunawa } \\
\text { Grudo }\end{array}$ & $\begin{array}{c}\text { Rusunawa } \\
\text { Penjaringan } \\
\text { Sari III } \\
\end{array}$ & $\begin{array}{l}\text { Rusunawa } \\
\text { Siwalankerto }\end{array}$ & Total \\
\hline \multicolumn{7}{|l|}{ Jenis Kelamin } \\
\hline Pria & 16 & 41 & 25 & 38 & 28 & 148 \\
\hline Wanita & 9 & 9 & 14 & 15 & 15 & 62 \\
\hline \multicolumn{7}{|l|}{ Usia } \\
\hline$<36$ & 1 & 9 & 2 & 5 & 8 & 25 \\
\hline $36-45$ & 9 & 17 & 9 & 17 & 15 & 67 \\
\hline $46-55$ & 9 & 20 & 21 & 13 & 15 & 78 \\
\hline$>55$ & 6 & 4 & 7 & 18 & 5 & 40 \\
\hline \multicolumn{7}{|l|}{ Pendidikan } \\
\hline$=<\mathrm{SD}$ & 3 & 3 & 8 & 12 & 10 & 36 \\
\hline SMP, SLTP & 5 & 8 & 6 & 12 & 6 & 37 \\
\hline SMK,SMA, SLTA, STM & 16 & 36 & 23 & 23 & 22 & 120 \\
\hline S1, D3 & 1 & 3 & 2 & 6 & 5 & 17 \\
\hline \multicolumn{7}{|l|}{ Pekerjaan } \\
\hline Swasta & 11 & 28 & 2 & 20 & 18 & 79 \\
\hline $\begin{array}{l}\text { Pegawai Swasta, } \\
\text { Pegawai Dinas, PNS }\end{array}$ & 8 & 8 & 17 & 14 & 2 & 49 \\
\hline $\begin{array}{l}\text { Ibu Rumah Tangga } \\
\text { Pekerja Lepas }\end{array}$ & 3 & 2 & 8 & 4 & 8 & 25 \\
\hline $\begin{array}{l}\text { (Gojek,Pengamen,Sera } \\
\text { butan,Tukang harian) }\end{array}$ & 2 & 9 & 9 & 2 & 15 & 37 \\
\hline Pensiunan & 1 & 1 & 3 & 12 & 0 & 17 \\
\hline $\begin{array}{l}\text { DLL } \\
\text { (Rohaniwa,Instalatis) }\end{array}$ & 0 & 2 & 0 & 1 & 0 & 3 \\
\hline \multicolumn{7}{|l|}{ Penghasilan Kotor } \\
\hline$<1.500 .000$ & 6 & 9 & 7 & 4 & 14 & 40 \\
\hline $1.500 .000-3.800 .000$ & 15 & 27 & 7 & 30 & 26 & 105 \\
\hline$>3.800 .000$ & 4 & 14 & 25 & 19 & 3 & 65 \\
\hline
\end{tabular}


Tabel 2. Dekripsi kondisi sewa penghuni

\begin{tabular}{|c|c|c|c|c|c|c|}
\hline Informasi & $\begin{array}{l}\text { Rusunawa } \\
\text { Jambangan }\end{array}$ & $\begin{array}{l}\text { Rusunawa } \\
\text { Menanggal }\end{array}$ & $\begin{array}{c}\text { Rusunaw } \\
\text { a } \\
\text { Grudo }\end{array}$ & $\begin{array}{c}\text { Rusunawa } \\
\text { Penjaringan } \\
\text { Sari III }\end{array}$ & $\begin{array}{c}\text { Rusunawa } \\
\text { Siwalankerto }\end{array}$ & Total \\
\hline \multicolumn{7}{|l|}{ Lantai } \\
\hline Lantai 1 & 0 & 1 & 2 & 0 & 3 & $6(3 \%)$ \\
\hline Lantai 2 & 6 & 10 & 9 & 18 & 9 & $52(25 \%)$ \\
\hline Lantai 3 & 8 & 14 & 9 & 14 & 7 & $52(25 \%)$ \\
\hline Lantai 4 & 6 & 12 & 11 & 11 & 13 & $53(25 \%)$ \\
\hline Lantai 5 & 6 & 12 & 8 & 10 & 11 & $47(22 \%)$ \\
\hline $\begin{array}{l}\text { Biaya Sewa Per } \\
\text { Bulan }\end{array}$ & & \\
\hline$<45.000$ & 6 & 12 & 8 & 10 & 11 & $47(22 \%)$ \\
\hline $45.000-65.000$ & 6 & 9 & 21 & 25 & 22 & $83(40 \%)$ \\
\hline$>65.000$ & 14 & 28 & 10 & 18 & 10 & $80(38 \%)$ \\
\hline $\begin{array}{l}\text { Lama } \\
\text { (Tahun) }\end{array}$ & & & & & & \\
\hline 2 & 0 & 25 & 2 & 0 & 1 & $28(13 \%)$ \\
\hline 3 & 1 & 23 & 8 & 19 & 6 & $57(27 \%)$ \\
\hline 4 & 0 & 1 & 9 & 9 & 16 & $35(17 \%)$ \\
\hline $\begin{array}{l}>4 \\
\text { Mengajukan } \\
\text { Kerusakan (Kali) }\end{array}$ & 25 & 0 & 20 & 25 & 20 & $90(43 \%)$ \\
\hline $1-2$ & 14 & 24 & 14 & 13 & 22 & $87(41 \%)$ \\
\hline $3-4$ & 5 & 11 & 19 & 26 & 14 & $75(36 \%)$ \\
\hline$>4$ & 7 & 14 & 6 & 14 & 7 & $48(23 \%)$ \\
\hline
\end{tabular}

\section{Uji Validitas dan Reliabilitas}

Sebelum data dikelola, diperlukan uji validitas dan reliabilitas untuk mengetahui valid dan reliabel tidaknya data tersebut. Uji validitas dilakukan menggunakan korelasi Pearson yaitu dengan mencari tingkat kekuatan hubungan setiap variabel. Sedangkan Uji realibilitas merupakan alat untuk mengukur konsistensi dan stabilitas dari jawaban responden terhadap pertanyaan pada kuisioner. Pengujian dilakukan dengan mencari nilai alpha melalui formula Cronbach. Hasil uji validitas dan reliabilitas prioritas perawatan dapat dilihat pada Tabel 3 dan hasil uji validitas dan reliabilitas alasan dilakukan perawatan dapat dilihat pada Tabel 4.

Tabel 3. Hasil Uji Validitas dan Reliabilitas Prioritas Perawatan

\begin{tabular}{|c|c|c|c|}
\hline Kode & Indikator & $\begin{array}{c}\text { Validitas } \\
\text { (Pearson } \\
\text { Correlation) }\end{array}$ & $\begin{array}{c}\text { Reliabilitas } \\
\text { (Cronbach's } \\
\text { Alpha) }\end{array}$ \\
\hline PPS & Perawatan Kerusakan Struktur & & \multirow{7}{*}{0.916} \\
\hline PPS1 & Terdapat retak/lubang pada kolom / tiang beton & $.879^{\star \star}$ & \\
\hline PPS2 & Terdapat retak/lubang pada balok beton & $.895^{\star *}$ & \\
\hline PPS3 & Terdapat retak/lubang pada plat / dak talang atau kanopi & $.917^{\star *}$ & \\
\hline PPS4 & $\begin{array}{l}\text { Terdapat retak vertical, horizontal maupun diagonal pada } \\
\text { dinding bata }\end{array}$ & $.871^{\star \star}$ & \\
\hline PPS5 & Terdapat retak pada tangga beton dan bergetar saat diinjak & $.828^{\star *}$ & \\
\hline PPA & Perawatan Kerusakan Arsitektur & & \\
\hline PPA1 & Kondisi plafon/langit-langit terdapat banyak noda,retak, rongga & $.730^{\star *}$ & \multirow{6}{*}{0.861} \\
\hline PPA2 & Plesteran/cat dinding terkelupas dan berjatuhan & $.768^{\star *}$ & \\
\hline PPA3 & $\begin{array}{l}\text { Terdapat dinding pembatas (partisi) yang rusak / jebol / } \\
\text { berlubang }\end{array}$ & $.786^{\star \star}$ & \\
\hline PPA4 & Kondisi kusen/bingkai pintu dan jendela rusak / lapuk & $.777^{\star \star}$ & \\
\hline PPA5 & $\begin{array}{l}\text { Kondisi daun pintu dan aksesoris pintu (handle, mortise, door } \\
\text { stopper) rusak }\end{array}$ & $.793^{\star \star}$ & \\
\hline PPA6 & Kondisi keramik dinding pecah, retak & $.840^{* *}$ & \\
\hline
\end{tabular}




\begin{tabular}{|c|c|c|c|}
\hline Kode & Indikator & $\begin{array}{c}\text { Validitas } \\
\text { (Pearson } \\
\text { Correlation) }\end{array}$ & $\begin{array}{c}\text { Reliabilitas } \\
\text { (Cronbach's } \\
\text { Alpha) }\end{array}$ \\
\hline PPA7 & Kondisi keramik lantai pecah, retak & $.787^{\star *}$ & \multirow{12}{*}{0.882} \\
\hline PPU & Perawatan Kerusakan Utilitas & & \\
\hline PPU1 & Jumlah titik kebocoran pada ruangan & $.677^{\star \star}$ & \\
\hline PPU2 & Kebocoran talang air kanopi sering terjadi & $.676^{\star *}$ & \\
\hline PPU3 & Instalasi air bersih (jalur pipa, kran, wastafel) bermasalah,bocor & $.775^{\star \star}$ & \\
\hline PPU4 & $\begin{array}{l}\text { Kualitas air bersih yang di hasilkan keruh, berbau, } \\
\text { mampet/macet }\end{array}$ & $.697^{\star \star}$ & \\
\hline PPU5 & $\begin{array}{l}\text { Terjadi konsleting listrik dikarenakan instalasi listrik tidak } \\
\text { sempurna (njegeleg) }\end{array}$ & $.687^{\star \star}$ & \\
\hline PPU6 & Aliran listrik(PLN) sering terputus/padam (mati lampu) & $.686^{\star *}$ & \\
\hline PPU7 & $\begin{array}{l}\text { Terjadi bau kurang sedap akibat pengolahan limbah air kotor/ } \\
\text { kotoran (wastafel, dapur, kloset, kamar mandi) }\end{array}$ & $.715^{\star \star}$ & \\
\hline PPU8 & Kerusakan/kebocoran alat sanitasi ( kloset, avur, kran, wastafel) & $.739^{\star \star}$ & \\
\hline PPU9 & Kerusakan pada saklar/stopkontak & $.776^{\star \star}$ & \\
\hline $\begin{array}{l}\text { PPU1 } \\
0\end{array}$ & $\begin{array}{l}\text { Saluran pipa pada pembuangan tersumbat,bocor,mampet } \\
\text { sehingga menimbulkan genangan air }\end{array}$ & $.710^{\star *}$ & \\
\hline
\end{tabular}

Tabel 4. Hasil Uji Validitas dddan Reliabilitas Alasan Perawatan

\begin{tabular}{|c|c|c|c|}
\hline Kode & Indikator & $\begin{array}{l}\text { Validitas } \\
\text { (Pearson } \\
\text { Correlation) }\end{array}$ & $\begin{array}{l}\text { Reliabilitas } \\
\text { (Cronbach's } \\
\text { Alpha) }\end{array}$ \\
\hline AS & Alasan dilakukan Tindakan Perawatan Struktur & & \multirow{5}{*}{0.809} \\
\hline AS1 & $\begin{array}{l}\text { Pekerjaan yang diperlukan untuk menjaga keselamatan dan } \\
\text { kenyamanan penghuni }\end{array}$ & $.761^{\star \star}$ & \\
\hline AS2 & $\begin{array}{l}\text { Mencegah kerusakan struktur yang fatal pada bagian penting } \\
\text { gedung / bangunan yang dapat menyebabkan bangunan } \\
\text { roboh }\end{array}$ & $.857^{\star \star}$ & \\
\hline AS3 & $\begin{array}{l}\text { Pengecekan secara rutin untuk mencegah terjadinya } \\
\text { kerusakan pada struktur bangunan (kolom/tiang, balok, } \\
\text { dek/plat) }\end{array}$ & $.863^{\star *}$ & \\
\hline AS4 & $\begin{array}{l}\text { Perbaikan material bangunan struktur untuk bangunan tetap } \\
\text { kokoh }\end{array}$ & $.816^{\star \star}$ & \\
\hline AA & Alasan dilakukan Tindakan Perawatan Arsitektur & & \multirow{5}{*}{0.832} \\
\hline AA1 & $\begin{array}{l}\text { Pengecekan secara rutin untuk mencegah terjadinya } \\
\text { kerusakan pada tampilan/tampak bangunan }\end{array}$ & $.785^{\star \star}$ & \\
\hline AA2 & $\begin{array}{l}\text { Mencegah kerusakan arsitektur yang fatal (plafon, cat, } \\
\text { keramik) }\end{array}$ & $.867^{\star \star}$ & \\
\hline AA3 & Pekerjaan yang diperlukan untuk penampilan fisik properti & $.824^{\star \star}$ & \\
\hline AA4 & $\begin{array}{l}\text { Perbaikan material bangunan arsitektur/tampak } \\
\text { (plafon,cat,pintu) }\end{array}$ & $.848^{\star *}$ & \\
\hline AU & Alasan dilakukan Tindakan Perawatan Utilitas & & \multirow{6}{*}{0.83} \\
\hline AU1 & $\begin{array}{l}\text { Pekerjaan yang diperlukan untuk menjaga bangunan tetap } \\
\text { berfungsi dan layak dihuni }\end{array}$ & $.735^{\star \star}$ & \\
\hline AU2 & $\begin{array}{l}\text { Pekerjaan yang diperlukan untuk menjaga bangunan tetap } \\
\text { beroperasi atau berjalan dengan baik }\end{array}$ & $.770^{\star \star}$ & \\
\hline AU3 & $\begin{array}{l}\text { Mencegah kerusakan utilitas yang fatal (kebocoran, konslet, } \\
\text { pipa tersumbat) }\end{array}$ & $.833^{\star \star}$ & \\
\hline AU4 & $\begin{array}{l}\text { Pengecekan secara rutin untuk mencegah terjadinya } \\
\text { kerusakan utilitas (pipa air, kabel listrik) }\end{array}$ & $.864^{\star \star}$ & \\
\hline AU5 & $\begin{array}{l}\text { Perbaikan material bangunan utilitas (pipa air, kabel listrik, } \\
\text { saklar, stopkontak) }\end{array}$ & $.760^{\star \star}$ & \\
\hline
\end{tabular}

Keterangan: ${ }^{\star \star}$ signifikan pada $\alpha=0.05$ 


\section{Uji Prioritas Perawatan dan Alasan Dilakukan Perawatan Penghuni Masing-Masing Rusunawa}

Berdasarkan hasil uji normalitas yang telah dilakukan, terdapat data tidak berdistribusi secara normal. Maka dari itu, uji dilakukan menggunakan Kruskal Wallis. Uji Kruskal Wallis dilakukan untuk mengetahui perbedaan pendapat antar rusunawa terhadap prioritas perawatan. Pengambilan keputusan terhadap penelitian didasari nilai signifikan. Untuk menentukan urutan alasan dilakukan perawatan menurut penghuni rusunawa digunakan uji mean dan standard deviation sebagai acuan jika nilai mean hasil olah data adalah sama. Perbedaan nilai mean perawatan dapat dilihat pada Tabel 5 dan alasan dilakukan tindakan perawatan dapat dilihat Tabel 6 .

Tabel 5. Perbedaan nilai mean perawatan masing-masing rusunawa

\begin{tabular}{|c|c|c|c|c|c|c|c|c|c|c|}
\hline \multirow{2}{*}{ Keterangan } & \multicolumn{2}{|c|}{$\begin{array}{l}\text { Rusunawa } \\
\text { Jambangan }\end{array}$} & \multicolumn{2}{|c|}{$\begin{array}{l}\text { Rusunawa } \\
\text { Menanggal }\end{array}$} & \multicolumn{2}{|c|}{$\begin{array}{l}\text { Rusunawa } \\
\text { Grudo }\end{array}$} & \multicolumn{2}{|c|}{$\begin{array}{c}\text { Rusunawa } \\
\text { Penjaringan Sari } \\
\text { III }\end{array}$} & \multicolumn{2}{|c|}{$\begin{array}{c}\text { Rusunawa } \\
\text { Siwalankerto }\end{array}$} \\
\hline & $\begin{array}{c}\text { Mean } \\
(\mu)\end{array}$ & $\begin{array}{l}\text { Std. } \\
\text { Dev. } \\
\text { (Sd) }\end{array}$ & $\begin{array}{c}\text { Mean } \\
(\mu)\end{array}$ & $\begin{array}{l}\text { Std. } \\
\text { Dev. } \\
(\text { Sd) }\end{array}$ & $\begin{array}{c}\text { Mean } \\
(\mu)\end{array}$ & $\begin{array}{l}\text { Std. } \\
\text { Dev. } \\
\text { (Sd) }\end{array}$ & $\begin{array}{c}\text { Mean } \\
(\mu)\end{array}$ & $\begin{array}{l}\text { Std. } \\
\text { Dev. } \\
\text { (Sd) }\end{array}$ & $\begin{array}{c}\text { Mean } \\
(\mu)\end{array}$ & $\begin{array}{l}\text { Std. } \\
\text { Dev. } \\
\text { ( Sd) }\end{array}$ \\
\hline $\begin{array}{l}\text { Perawatan } \\
\text { Struktur }\end{array}$ & $\begin{array}{r}5.736 \\
(1)^{\star}\end{array}$ & 0.345 & $\begin{array}{r}5.428 \\
(3)^{*}\end{array}$ & 0.416 & $\begin{array}{r}4.779 \\
(2)^{\star}\end{array}$ & 0.758 & $\begin{array}{r}5.336 \\
(2)^{*}\end{array}$ & 0.520 & $\begin{array}{r}5.298 \\
(2)^{*}\end{array}$ & 0.517 \\
\hline $\begin{array}{l}\text { Perawatan kolom } \\
\text { beton }\end{array}$ & $\begin{array}{r}5.880 \\
(1)\end{array}$ & 0.332 & $\begin{array}{r}5.040 \\
(5)\end{array}$ & 0.450 & $\begin{array}{r}4.718 \\
(4)\end{array}$ & 0.826 & $\begin{array}{r}5.321 \\
(3)\end{array}$ & 0.644 & $\begin{array}{r}5.279 \\
(4)\end{array}$ & 0.697 \\
\hline $\begin{array}{l}\text { Perawatan balok } \\
\text { beton }\end{array}$ & $\begin{array}{r}5.800 \\
(2)\end{array}$ & 0.408 & $\begin{array}{r}5.060 \\
(4)\end{array}$ & 0.470 & $\begin{array}{r}4.718 \\
(4)\end{array}$ & 0.826 & $\begin{array}{r}5.340 \\
(2)\end{array}$ & 0.586 & $\begin{array}{r}5.302 \\
(3)\end{array}$ & 0.671 \\
\hline $\begin{array}{l}\text { Perawatan dak } \\
\text { beton }\end{array}$ & $\begin{array}{r}5.800 \\
(2)\end{array}$ & 0.408 & $\begin{array}{r}5.440 \\
(3)\end{array}$ & 0.644 & $\begin{array}{r}4.769 \\
(3)\end{array}$ & 0.777 & $\begin{array}{r}5.358 \\
(1)\end{array}$ & 0.558 & $\begin{array}{r}5.326 \\
(1)\end{array}$ & 0.675 \\
\hline $\begin{array}{l}\text { Perawatan } \\
\text { dinding bata }\end{array}$ & $\begin{array}{r}5.600 \\
(4)\end{array}$ & 0.577 & $\begin{array}{r}5.760 \\
(2)\end{array}$ & 0.517 & $\begin{array}{r}4.846 \\
(2)\end{array}$ & 0.779 & $\begin{array}{r}5.358 \\
(1)\end{array}$ & 0.558 & $\begin{array}{r}5.326 \\
(2)\end{array}$ & 0.669 \\
\hline $\begin{array}{l}\text { Perawatan tangga } \\
\text { beton }\end{array}$ & $\begin{array}{r}5.600 \\
(5) \\
\end{array}$ & 0.645 & $\begin{array}{r}5.840 \\
(1) \\
\end{array}$ & 0.468 & $\begin{array}{r}4.846 \\
(1) \\
\end{array}$ & 0.779 & $\begin{array}{r}5.302 \\
(4) \\
\end{array}$ & 0.668 & $\begin{array}{r}5.256 \\
(5) \\
\end{array}$ & 0.729 \\
\hline $\begin{array}{l}\text { Perawatan } \\
\text { Arsitektur }\end{array}$ & $\begin{array}{r}5.400 \\
(3)^{\star}\end{array}$ & 0.314 & $\begin{array}{r}5.474 \\
(2)^{\star}\end{array}$ & 0.286 & $\begin{array}{r}4.725 \\
(3)^{\star}\end{array}$ & 0.872 & $\begin{array}{r}5.124 \\
(3)^{\star}\end{array}$ & 0.514 & $\begin{array}{r}5.216 \\
(3)^{\star}\end{array}$ & 0.485 \\
\hline Perawatan plafon & $\begin{array}{r}5.400 \\
(3)\end{array}$ & 0.500 & $\begin{array}{r}5.060 \\
(7)\end{array}$ & 0.314 & $\begin{array}{r}4.821 \\
(4)\end{array}$ & 0.854 & $\begin{array}{r}5.208 \\
(1)\end{array}$ & 0.689 & $\begin{array}{r}5.302 \\
(2)\end{array}$ & 0.655 \\
\hline $\begin{array}{l}\text { Perawatan } \\
\text { plester/cat }\end{array}$ & $\begin{array}{r}5.480 \\
(2)\end{array}$ & 0.510 & $\begin{array}{r}5.160 \\
(6)\end{array}$ & 0.468 & $\begin{array}{r}4.821 \\
(4)\end{array}$ & 0.854 & $\begin{array}{r}5.057 \\
(6)\end{array}$ & 0.745 & $\begin{array}{r}5.186 \\
(5)\end{array}$ & 0.696 \\
\hline $\begin{array}{l}\text { Perawatan } \\
\text { dinding partisi }\end{array}$ & $\begin{array}{r}5.280 \\
(6)\end{array}$ & 0.542 & $\begin{array}{r}5.620 \\
(3)\end{array}$ & 0.530 & $\begin{array}{r}4.846 \\
(3)\end{array}$ & 0.812 & $\begin{array}{r}5.113 \\
(5)\end{array}$ & 0.725 & $\begin{array}{r}5.163 \\
(6)\end{array}$ & 0.717 \\
\hline $\begin{array}{l}\text { Perawatan kusen } \\
\text { pintu/jendela }\end{array}$ & $\begin{array}{r}5.600 \\
(1)\end{array}$ & 0.500 & $\begin{array}{r}5.520 \\
(5)\end{array}$ & 0.580 & $\begin{array}{r}4.923 \\
(1)\end{array}$ & 0.839 & $\begin{array}{r}5.170 \\
(3)\end{array}$ & 0.700 & $\begin{array}{r}5.326 \\
(1)\end{array}$ & 0.689 \\
\hline $\begin{array}{l}\text { Perawatan daun } \\
\text { pintu }\end{array}$ & $\begin{array}{r}5.280 \\
(5)\end{array}$ & 0.458 & $\begin{array}{r}5.720 \\
(1)\end{array}$ & 0.497 & $\begin{array}{r}4.897 \\
(2)\end{array}$ & 0.882 & $\begin{array}{r}5.170 \\
(2)\end{array}$ & 0.672 & $\begin{array}{r}5.233 \\
(3)\end{array}$ & 0.705 \\
\hline $\begin{array}{l}\text { Perawatan } \\
\text { keramik dinding }\end{array}$ & $\begin{array}{r}5.400 \\
(3)\end{array}$ & 0.500 & $\begin{array}{r}5.600 \\
(4)\end{array}$ & 0.535 & $\begin{array}{r}4.385 \\
(5)\end{array}$ & 1.330 & $\begin{array}{r}5.113 \\
(4)\end{array}$ & 0.610 & $\begin{array}{r}5.209 \\
(4)\end{array}$ & 0.860 \\
\hline $\begin{array}{l}\text { Perawatan } \\
\text { keramik lantai }\end{array}$ & $\begin{array}{r}5.360 \\
(4) \\
\end{array}$ & 0.490 & $\begin{array}{r}5.640 \\
(2) \\
\end{array}$ & 0.802 & $\begin{array}{r}4.385 \\
(5) \\
\end{array}$ & 1.330 & $\begin{array}{r}5.038 \\
(7) \\
\end{array}$ & 0.649 & $\begin{array}{r}5.093 \\
(7) \\
\end{array}$ & 0.919 \\
\hline Perawatan Utilitas & $\begin{array}{r}5.548 \\
(2)^{\star}\end{array}$ & 0.350 & $\begin{array}{r}5.562 \\
(1)^{\star}\end{array}$ & 0.194 & $\begin{array}{r}4.931 \\
(1)^{\star}\end{array}$ & 0.808 & $\begin{array}{r}5.423 \\
(1)^{\star}\end{array}$ & 0.346 & $\begin{array}{r}5.421 \\
(1)^{\star}\end{array}$ & 0.369 \\
\hline $\begin{array}{l}\text { Perawatan } \\
\text { kecoboran } \\
\text { ruangan }\end{array}$ & $\begin{array}{r}5.840 \\
(1)\end{array}$ & 0.374 & $\begin{array}{r}5.120 \\
(7)\end{array}$ & 0.328 & $\begin{array}{r}5.026 \\
(3)\end{array}$ & 0.811 & $\begin{array}{r}5.528 \\
(2)\end{array}$ & 0.608 & $\begin{array}{r}5.442 \\
(4)\end{array}$ & 0.635 \\
\hline $\begin{array}{l}\text { Perawatan } \\
\text { kebocoran talang }\end{array}$ & $\begin{array}{r}5.760 \\
(2)\end{array}$ & 0.436 & $\begin{array}{r}5.220 \\
(6)\end{array}$ & 0.418 & $\begin{array}{r}5.051 \\
(2)\end{array}$ & 0.826 & $\begin{array}{r}5.491 \\
(3)\end{array}$ & 0.541 & $\begin{array}{r}5.512 \\
(2)\end{array}$ & 0.609 \\
\hline $\begin{array}{l}\text { Perawatan } \\
\text { instalasi air }\end{array}$ & $\begin{array}{r}5.640 \\
(3)\end{array}$ & 0.490 & $\begin{array}{r}5.660 \\
(3)\end{array}$ & 0.479 & $\begin{array}{r}5.026 \\
(4)\end{array}$ & 0.843 & $\begin{array}{r}5.566 \\
(1)\end{array}$ & 0.572 & $\begin{array}{r}5.558 \\
(1)\end{array}$ & 0.636 \\
\hline $\begin{array}{l}\text { Perawatan } \\
\text { kualitas air }\end{array}$ & $\begin{array}{r}5.400 \\
(6)\end{array}$ & 0.577 & $\begin{array}{r}5.660 \\
(3)\end{array}$ & 0.479 & $\begin{array}{r}5.103 \\
(1)\end{array}$ & 0.788 & $\begin{array}{r}5.453 \\
(4)\end{array}$ & 0.607 & $\begin{array}{r}5.465 \\
(3)\end{array}$ & 0.632 \\
\hline $\begin{array}{l}\text { Perawatan aliran } \\
\text { listrik }\end{array}$ & $\begin{array}{r}5.400 \\
(6)\end{array}$ & 0.577 & $\begin{array}{r}5.700 \\
(2)\end{array}$ & 0.463 & $\begin{array}{r}5.103 \\
(1)\end{array}$ & 0.788 & $\begin{array}{r}5.340 \\
(9)\end{array}$ & 0.649 & $\begin{array}{r}5.349 \\
(9)\end{array}$ & 0.656 \\
\hline
\end{tabular}




\begin{tabular}{|c|c|c|c|c|c|c|c|c|c|c|}
\hline \multirow{2}{*}{ Keterangan } & \multicolumn{2}{|c|}{$\begin{array}{l}\text { Rusunawa } \\
\text { Jambangan }\end{array}$} & \multicolumn{2}{|c|}{$\begin{array}{l}\text { Rusunawa } \\
\text { Menanggal }\end{array}$} & \multicolumn{2}{|c|}{$\begin{array}{l}\text { Rusunawa } \\
\text { Grudo }\end{array}$} & \multicolumn{2}{|c|}{$\begin{array}{c}\text { Rusunawa } \\
\text { Penjaringan Sari } \\
\text { III }\end{array}$} & \multicolumn{2}{|c|}{$\begin{array}{c}\text { Rusunawa } \\
\text { Siwalankerto }\end{array}$} \\
\hline & $\begin{array}{c}\text { Mean } \\
(\mu)\end{array}$ & $\begin{array}{l}\text { Std. } \\
\text { Dev. } \\
\text { (Sd) }\end{array}$ & $\begin{array}{c}\text { Mean } \\
(\mu)\end{array}$ & $\begin{array}{l}\text { Std. } \\
\text { Dev. } \\
\text { (Sd) }\end{array}$ & $\begin{array}{c}\text { Mean } \\
(\mu)\end{array}$ & $\begin{array}{l}\text { Std. } \\
\text { Dev. } \\
\text { (Sd) }\end{array}$ & $\begin{array}{c}\text { Mean } \\
(\mu)\end{array}$ & $\begin{array}{l}\text { Std. } \\
\text { Dev. } \\
\text { (Sd) }\end{array}$ & $\begin{array}{c}\text { Mean } \\
(\mu)\end{array}$ & $\begin{array}{l}\text { Std. } \\
\text { Dev. } \\
\text { ( Sd) }\end{array}$ \\
\hline $\begin{array}{l}\text { Perawatan pada } \\
\text { instalasi listrik }\end{array}$ & $\begin{array}{r}5.480 \\
(5)\end{array}$ & 0.586 & $\begin{array}{r}5.620 \\
(3)\end{array}$ & 0.490 & $\begin{array}{r}5.103 \\
(1)\end{array}$ & 0.788 & $\begin{array}{r}5.302 \\
(10)\end{array}$ & 0.668 & $\begin{array}{r}5.302 \\
(10)\end{array}$ & 0.665 \\
\hline $\begin{array}{l}\text { Perawatan } \\
\text { pengelolaan } \\
\text { limbah }\end{array}$ & $\begin{array}{r}5.440 \\
(7)\end{array}$ & 0.583 & $\begin{array}{r}5.560 \\
(5)\end{array}$ & 0.501 & $\begin{array}{r}4.974 \\
(5)\end{array}$ & 0.873 & $\begin{array}{r}5.415 \\
(5)\end{array}$ & 0.663 & $\begin{array}{r}5.395 \\
(5)\end{array}$ & 0.687 \\
\hline $\begin{array}{l}\text { Perawatan } \\
\text { kebocoran alat } \\
\text { sanitasi }\end{array}$ & $\begin{array}{r}5.560 \\
(4)\end{array}$ & 0.507 & $\begin{array}{r}5.600 \\
(4)\end{array}$ & 0.495 & $\begin{array}{r}4.667 \\
(6)\end{array}$ & 1.132 & $\begin{array}{r}5.396 \\
(6)\end{array}$ & 0.689 & $\begin{array}{r}5.395 \\
(6)\end{array}$ & 0.796 \\
\hline $\begin{array}{l}\text { Perawatan } \\
\text { saklar/stopkonta } \\
\text { k }\end{array}$ & $\begin{array}{c}5.400 \\
(6)\end{array}$ & 0.577 & $\begin{array}{c}5.660 \\
(3)\end{array}$ & 0.479 & $\begin{array}{c}4.615 \\
(8)\end{array}$ & 1.227 & $\begin{array}{c}5.377 \\
(7)\end{array}$ & 0.596 & $\begin{array}{c}5.395 \\
(7)\end{array}$ & 0.809 \\
\hline $\begin{array}{l}\text { Perawatan } \\
\text { saluran } \\
\text { pembuangan air }\end{array}$ & $\begin{array}{c}5.560 \\
(4)\end{array}$ & 0.507 & $\begin{array}{c}5.820 \\
(1)\end{array}$ & 0.388 & $\begin{array}{c}4.641 \\
(7)\end{array}$ & 1.181 & $\begin{array}{l}5.358 \\
(8)\end{array}$ & 0.710 & $\begin{array}{l}5.395 \\
(8)\end{array}$ & 0.821 \\
\hline
\end{tabular}

Keterangan: * perbedaan antar rusunawa signifikan pada $\alpha=0.05$

Tabel 6. Perbedaan nilai mean alasan dilakukan perawatan masing-masing rusunawa

\begin{tabular}{|c|c|c|c|c|c|c|c|c|c|c|}
\hline \multirow{2}{*}{ Keterangan } & \multicolumn{2}{|c|}{$\begin{array}{l}\text { Rusunawa } \\
\text { Jambangan }\end{array}$} & \multicolumn{2}{|c|}{$\begin{array}{l}\text { Rusunawa } \\
\text { Menanggal }\end{array}$} & \multicolumn{2}{|c|}{$\begin{array}{l}\text { Rusunawa } \\
\text { Grudo }\end{array}$} & \multicolumn{2}{|c|}{$\begin{array}{c}\text { Rusunawa } \\
\text { Penjaringan } \\
\text { Sari III }\end{array}$} & \multicolumn{2}{|c|}{$\begin{array}{l}\text { Rusunawa } \\
\text { Siwalankerto }\end{array}$} \\
\hline & Mean $(\mu$ & $\begin{array}{l}\text { Std. } \\
\text { Dev. } \\
\text { (Sd) }\end{array}$ & $\begin{array}{c}\text { Mean } \\
(\mu)\end{array}$ & $\begin{array}{l}\text { Std. } \\
\text { Dev. } \\
\text { (Sd) }\end{array}$ & $\begin{array}{c}\text { Mea } \\
n \\
(\mu)\end{array}$ & $\begin{array}{l}\text { Std. } \\
\text { Dev. } \\
\text { (Sd) }\end{array}$ & $\begin{array}{c}\text { Mean } \\
(\mu)\end{array}$ & $\begin{array}{l}\text { Std. } \\
\text { Dev. } \\
\text { (Sd) }\end{array}$ & $\begin{array}{c}\text { Mean } \\
(\mu)\end{array}$ & $\begin{array}{l}\text { Std. } \\
\text { Dev. } \\
\text { ( Sd) }\end{array}$ \\
\hline $\begin{array}{l}\text { Alasan dilakukan Tindakan } \\
\text { Perawatan Struktur }\end{array}$ & $\begin{array}{r}5.660 \\
(1)^{\star}\end{array}$ & 0.525 & $\begin{array}{r}5.405 \\
(3)^{\star}\end{array}$ & 0.285 & $\begin{array}{r}5.019 \\
(1)^{*}\end{array}$ & 0.770 & $\begin{array}{r}4.981 \\
(3)^{\star}\end{array}$ & 0.500 & $\begin{array}{r}5.401 \\
(1)^{\star}\end{array}$ & 0.470 \\
\hline $\begin{array}{l}\text { Pekerjaan yang diperlukan } \\
\text { untuk menjaga keselamatan } \\
\text { dan kenyamanan penghuni }\end{array}$ & $\begin{array}{r}5.800 \\
(1)\end{array}$ & 0.500 & $\begin{array}{r}5.040 \\
(4)\end{array}$ & 0.283 & $\begin{array}{r}5.000 \\
(2)\end{array}$ & 0.761 & $\begin{array}{r}5.340 \\
(1)\end{array}$ & 0.706 & $\begin{array}{r}5.512 \\
(1)\end{array}$ & 0.592 \\
\hline $\begin{array}{l}\text { Mencegah kerusakan struktur } \\
\text { yang fatal pada bagian penting } \\
\text { gedung /bangunan yang } \\
\text { dapat menyebabkan } \\
\text { bangunan roboh }\end{array}$ & $\begin{array}{r}5.800 \\
(1)\end{array}$ & 0.500 & $\begin{array}{r}5.200 \\
(3)\end{array}$ & 0.452 & $\begin{array}{r}5.026 \\
(1)\end{array}$ & 0.778 & $\begin{array}{r}4.811 \\
(3)\end{array}$ & 0.735 & $\begin{array}{r}5.465 \\
(2)\end{array}$ & 0.592 \\
\hline $\begin{array}{l}\text { Pengecekan secara rutin } \\
\text { untuk mencegah terjadinya } \\
\text { kerusakan pada struktur } \\
\text { bangunan (kolom/tiang, } \\
\text { balok, dek/plat) }\end{array}$ & $\begin{array}{r}5.640 \\
(2)\end{array}$ & 0.569 & $\begin{array}{r}5.620 \\
(2)\end{array}$ & 0.530 & $\begin{array}{r}5.026 \\
(1)\end{array}$ & 0.778 & $\begin{array}{r}4.698 \\
(4)\end{array}$ & 0.774 & $\begin{array}{r}5.326 \\
(3)\end{array}$ & 0.566 \\
\hline $\begin{array}{l}\text { Perbaikan material bangunan } \\
\text { struktur untuk bangunan tetap } \\
\text { kokoh }\end{array}$ & $\begin{array}{r}5.400 \\
(3)\end{array}$ & 1.080 & $\begin{array}{r}5.760 \\
(1)\end{array}$ & 0.555 & $\begin{array}{r}5.026 \\
(1)\end{array}$ & 0.778 & $\begin{array}{r}5.076 \\
(2)\end{array}$ & 0.615 & $\begin{array}{r}5.302 \\
(4)\end{array}$ & 0.599 \\
\hline $\begin{array}{l}\text { Alasan dilakukan Tindakan } \\
\text { Perawatan Arsitektur }\end{array}$ & $\begin{array}{r}5.490 \\
(3)^{\star}\end{array}$ & 0.442 & $\begin{array}{r}5.470 \\
(2)^{\star}\end{array}$ & 0.302 & $\begin{array}{r}4.577 \\
(3)^{*}\end{array}$ & 0.861 & $\begin{array}{r}5.288 \\
(1)^{\star}\end{array}$ & 0.458 & $\begin{array}{r}5.140 \\
(3)^{*}\end{array}$ & 0.588 \\
\hline $\begin{array}{l}\text { Pengecekan secara rutin } \\
\text { untuk mencegah terjadinya } \\
\text { kerusakan } \\
\text { tampilan/tampak bangunan }\end{array}$ & $\begin{array}{r}5.560 \\
(1)\end{array}$ & 0.507 & $\begin{array}{r}5.100 \\
(4)\end{array}$ & 0.416 & $\begin{array}{r}4.513 \\
(4)\end{array}$ & 0.970 & $\begin{array}{r}5.245 \\
(4)\end{array}$ & 0.853 & $\begin{array}{r}5.256 \\
(2)\end{array}$ & 0.790 \\
\hline $\begin{array}{l}\text { Mencegah kerusakan } \\
\text { arsitektur yang fatal (plafon, } \\
\text { cat, keramik) }\end{array}$ & $\begin{array}{r}5.400 \\
(4)\end{array}$ & 0.500 & $\begin{array}{r}5.260 \\
(3)\end{array}$ & 0.527 & $\begin{array}{r}4.564 \\
(3)\end{array}$ & 0.852 & $\begin{array}{r}5.283 \\
(3)\end{array}$ & 0.717 & $\begin{array}{r}5.256 \\
(1)\end{array}$ & 0.759 \\
\hline $\begin{array}{l}\text { Pekerjaan yang diperlukan } \\
\text { untuk penampilan fisik } \\
\text { properti }\end{array}$ & $\begin{array}{r}5.480 \\
(3)\end{array}$ & 0.510 & $\begin{array}{r}5.600 \\
(2)\end{array}$ & 0.495 & $\begin{array}{r}4.615 \\
(2)\end{array}$ & 0.877 & $\begin{array}{r}5.283 \\
(2)\end{array}$ & 0.601 & $\begin{array}{r}4.860 \\
(4)\end{array}$ & 1.014 \\
\hline
\end{tabular}




\begin{tabular}{|c|c|c|c|c|c|c|c|c|c|c|}
\hline \multirow{2}{*}{ Keterangan } & \multicolumn{2}{|c|}{$\begin{array}{l}\text { Rusunawa } \\
\text { Jambangan }\end{array}$} & \multicolumn{2}{|c|}{$\begin{array}{l}\text { Rusunawa } \\
\text { Menanggal }\end{array}$} & \multicolumn{2}{|c|}{$\begin{array}{l}\text { Rusunawa } \\
\text { Grudo }\end{array}$} & \multicolumn{2}{|c|}{$\begin{array}{c}\text { Rusunawa } \\
\text { Penjaringan } \\
\text { Sari III } \\
\end{array}$} & \multicolumn{2}{|c|}{$\begin{array}{l}\text { Rusunawa } \\
\text { Siwalankerto }\end{array}$} \\
\hline & Mean $(\mu$ & $\begin{array}{l}\text { Std. } \\
\text { Dev. } \\
(\text { Sd) }\end{array}$ & $\begin{array}{c}\text { Mean } \\
(\mu)\end{array}$ & $\begin{array}{l}\text { Std. } \\
\text { Dev. } \\
\text { (Sd) }\end{array}$ & $\begin{array}{c}\text { Mea } \\
\mathrm{n} \\
(\mu)\end{array}$ & $\begin{array}{l}\text { Std. } \\
\text { Dev. } \\
\text { (Sd) }\end{array}$ & $\begin{array}{c}\text { Mean } \\
(\mu)\end{array}$ & $\begin{array}{l}\text { Std. } \\
\text { Dev. } \\
\text { (Sd) }\end{array}$ & $\begin{array}{c}\text { Mean } \\
(\mu)\end{array}$ & $\begin{array}{l}\text { Std. } \\
\text { Dev. } \\
(\text { Sd) } \\
\end{array}$ \\
\hline $\begin{array}{l}\text { Perbaikan material bangunan } \\
\text { arsitektur/tampak } \\
\text { (plafon,cat,pintu) }\end{array}$ & $\begin{array}{r}5.520 \\
(2)\end{array}$ & 0.510 & $\begin{array}{r}5.920 \\
(1)\end{array}$ & 0.274 & $\begin{array}{r}4.615 \\
(1)\end{array}$ & 0.847 & $\begin{array}{r}5.340 \\
(1)\end{array}$ & 0.587 & $\begin{array}{r}5.186 \\
(3)\end{array}$ & 0.764 \\
\hline $\begin{array}{l}\text { Alasan dilakukan Tindakan } \\
\text { Perawatan Utilitas }\end{array}$ & $\begin{array}{r}5.552 \\
(2)^{\star}\end{array}$ & 0.307 & $\begin{array}{r}5.500 \\
(1)^{\star}\end{array}$ & 0.240 & $\begin{array}{r}4.923 \\
(2)^{\star}\end{array}$ & 0.749 & $\begin{array}{r}5.060 \\
(2)^{\star}\end{array}$ & 0.422 & $\begin{array}{r}5.377 \\
(2)^{\star}\end{array}$ & 0.568 \\
\hline $\begin{array}{l}\text { Pekerjaan yang diperlukan } \\
\text { untuk menjaga bangunan } \\
\text { tetap berfungsi dan layak } \\
\text { dihuni }\end{array}$ & $\begin{array}{r}5.560 \\
(3)\end{array}$ & 0.507 & $\begin{array}{r}5.140 \\
(5)\end{array}$ & 0.351 & $\begin{array}{r}4.949 \\
(1)\end{array}$ & 0.759 & $\begin{array}{r}5.038 \\
(4)\end{array}$ & 0.759 & $\begin{array}{r}5.465 \\
(1)\end{array}$ & 0.702 \\
\hline $\begin{array}{l}\text { Pekerjaan yang diperlukan } \\
\text { untuk menjaga bangunan } \\
\text { tetap beroperasi atau berjalan } \\
\text { dengan baik }\end{array}$ & $\begin{array}{r}5.720 \\
(1)\end{array}$ & 0.458 & $\begin{array}{r}5.220 \\
(4)\end{array}$ & 0.418 & $\begin{array}{r}4.949 \\
(1)\end{array}$ & 0.759 & $\begin{array}{r}4.981 \\
(5)\end{array}$ & 0.720 & $\begin{array}{r}5.372 \\
(3)\end{array}$ & 0.691 \\
\hline $\begin{array}{l}\text { Mencegah kerusakan utilitas } \\
\text { yang fatal (kebocoran, konslet, } \\
\text { pipa tersumbat) }\end{array}$ & $\begin{array}{r}5.680 \\
(2)\end{array}$ & 0.476 & $\begin{array}{r}5.520 \\
(3)\end{array}$ & 0.544 & $\begin{array}{r}4.897 \\
(3)\end{array}$ & 0.788 & $\begin{array}{r}5.057 \\
(3)\end{array}$ & 0.663 & $\begin{array}{r}5.256 \\
(5)\end{array}$ & 0.727 \\
\hline $\begin{array}{l}\text { Pengecekan secara rutin } \\
\text { untuk mencegah terjadinya } \\
\text { kerusakan utilitas ( pipa air, } \\
\text { kabel listrik) }\end{array}$ & $\begin{array}{r}5.360 \\
(5)\end{array}$ & 0.490 & $\begin{array}{r}5.800 \\
(2)\end{array}$ & 0.404 & $\begin{array}{r}4.897 \\
(3)\end{array}$ & 0.788 & $\begin{array}{r}5.076 \\
(2)\end{array}$ & 0.703 & $\begin{array}{r}5.442 \\
(2)\end{array}$ & 0.700 \\
\hline $\begin{array}{l}\text { Perbaikan material bangunan } \\
\text { utilitas (pipa air, kabel listrik, } \\
\text { saklar, stopkontak) }\end{array}$ & $\begin{array}{r}5.440 \\
(4)\end{array}$ & 0.507 & $\begin{array}{r}5.820 \\
(1)\end{array}$ & 0.388 & $\begin{array}{r}4.923 \\
(2)\end{array}$ & 0.774 & $\begin{array}{r}5.151 \\
(1)\end{array}$ & 0.770 & $\begin{array}{r}5.349 \\
(4)\end{array}$ & 0.813 \\
\hline
\end{tabular}

Keterangan: * perbedaan antar rusunawa signifikan pada $\alpha=0.05$

\section{Uji Korelasi Pearson}

Uji korelasi bertujuan mengetahui adanya keeratan hubungan antara dua variable yaitu variabel perawatan dan alasan dilakukan perawatan. Hasil uji korelasi Pearson dapat dilihat pada Tabel 7.

Tabel 7. Hasil uji korelasi Pearson

\begin{tabular}{lccc}
\hline \multicolumn{1}{c}{ Keterangan } & $\begin{array}{c}\text { Alasan dilakukan } \\
\text { Perawatan } \\
\text { Struktur }\end{array}$ & $\begin{array}{c}\text { Alasan dilakukan } \\
\text { Perawatan } \\
\text { Arsitektur }\end{array}$ & $\begin{array}{c}\text { Alasan dilakukan } \\
\text { Perawatan } \\
\text { Utilitas }\end{array}$ \\
\hline $\begin{array}{l}\text { Perawatan Struktur } \\
\text { Perawatan Arsitektur } \\
\text { Perawatan Utilitas }\end{array}$ & $.553^{\star *}$ & & $.622^{\star \star}$ \\
Keterangan: ${ }^{\star *}$ signifikan pada $\alpha=0.05$ & & & $.646^{\star \star}$ \\
\hline
\end{tabular}

Tabel 7 menunjukkan prioritas perawatan struktur berkorelasi positif dan signifikan ( $\mathrm{p}$ value $<0.05$ ) dengan alasan dilakukan perawatan struktur menurut penghuni, maka dapat dinyatakan bahwa semakin penting perawatan struktur maka semakin kuat alasan dilakukan perawatan struktur. Prioritas perawatan arsitektur dan utilitas juga berkorelasi positif dengan alasan dilakukan perawatan. 


\section{PEMBAHASAN}

Urutan tertinggi sampai terendah pada prioritas perawatan dan alasan dilakukan perawatan pada masing-masing penghuni rusunawa di Surabaya serta keeratan hubungan antara prioritas perawatan dan alasan dilakukan perawatan dijabarkan di bawah.

\section{Prioritas Perawatan}

Prioritas perawatan antara masing-masing rusunawa memiliki perbedaan signifikan baik struktur, arsitektur maupun utilitas. Urutan prioritas perawatan dari tertinggi sampai terendah berdasarkan nilai mean pada perawatan struktur, arsitektur, utilitas memiliki tingkat kepentingan yang berbeda-beda. Prioritas perawatan penghuni rusunawa Menanggal, Grudo, Penjaringan Sari III, dan Siwalankerto lebih mementingkan perawatan utilitas, sedangkan rusunawa Jambangan lebih mementingkan perawatan struktur. Sebaliknya prioritas perawatan tampilan bangunan atau façade lebih diutamakan pada penelitian Flores-Colen, Brito, \& Freitas (2010), namun pada penelitian ini lebih mementingkan perawatan utilitas dan struktur daripada perawatan arsitektur.

\section{Alasan Dilakukan Perawatan}

Alasan dilakukan perawatan menunjukkan perbedaan yang signifikan antar penghuni rusunawa. Tabel 6 menampilkan bahwa penghuni rusunawa Jambangan, Grudo dan Siwalankerto berpendapat bahwa alasan perawatan struktur adalah terpenting. Penghuni rusunawa Menanggal berpendapat yang terpenting alasan dilakukan perawat utilitas sedangkan rusunawa Penjaringan Sari III beranggapan alasan dilakukan perawatan arsitektur yang terpenting. Yusof, Abdullah, Zubedy \& Najib (2012) menyebutkan alasan dilakukan perawatan tertinggi adalah perawatan struktur untuk menjaga keselamatan dan kenyamanan penghuni. Hal ini sependapat dengan penghuni pada rusunawa Jambangan, Grudo, dan Siwalankerto. Perbedaan pendapat di antara ke-lima rusunawa tersebut menandakan setiap penghuni masing-masing rusunawa memiliki karakter dan tingkat kesadaran akan perawatan yang berbeda-beda.

\section{Korelasi Prioritas Perawatan dengan Alasan Dilakukan Perawatan}

Prioritas perawatan dan alasan dilakukan perawatan pada uji korelasi menunjukkan korelasi positif. Semakin penting prioritas perawatan struktur, arsitektur, dan utilitas maka semakin kuat alasan dilakukan perawatan struktur, arsitektur dan utilitas. Yusof, Abdullah, Zubedy \& Najib (2012) menyatakan adanya hubungan positif signifikan atau searah memberikan arti adanya hubungan yang erat antara prioritas perawatan dan alasan dilakukan perawatan, seperti yang sudah dibuktikan dalam penelitian ini.

\section{KESIMPULAN}

Berdasarkan hasil survei melalui kuesioner yang secara off-line pada masing-masing ke-lima rusunawa di Surabaya, menampilkan bahwa perawatan dan alasan dilakukan perawatan menurut penghuni merupakan hal yang penting. Penghuni rusunawa memiliki pendapat yang berbeda-beda terhadap prioritas perawatan dan alasan dilakukan perawatan. Prioritas perawatan utilitas dan struktur dianggap lebih penting oleh penghuni rusunawa dibanding perawatan arsitektur. Alasan dilakukan perawatan juga ditanggapi secara berbeda antar penghuni. Penghuni rusunawa Jambangan, Grudo, dan Siwalankerto lebih mementingkan alasan struktur. Rusunawa Menanggal lebih mementingkan alasan utilitas, sebaliknya penghuni rusunawa Penjaringan Sari III lebih mementingkan alasan arsitektur.

Adanya hubungan korelasi positif antara prioritas perawatan struktur, arsitektur, dan utilitas dengan alasan dilakukan perawatan. Semakin penting ke-tiga jenis perawatan maka 
alasan dilakukan perawatan juga semakin kuat. Dengan demikian hasil uji ini akan memberikan manfaat bagi manajemen pengelolaan rusunawa yaitu Pemerintah Kota Surabaya untuk menyusun strategi yang lebih baik terkait perawatan agar dapat mereduksi biaya kerusakan. Penghuni merupakan masyarakat berpenghasilan rendah sehingga kemampuan bayar jika terjadi kerusakan gedung akan sangat terbatas. Pengelola sebaiknya membuat gugus tugas pada masing-masing rusunawa untuk membantu kontrol kerusakan sehingga dapat diantisipasi atau diselesaikan dengan baik jika terjadi kerusakan bangunan. Dalam jangka panjang perawatan yang baik akan memberikan manfaat bagi penghuni terkait kenyamanan dan keamanan untuk tinggal di rusunawa.

\section{REFERENSI}

Arumsari, P., \& Rarasati, A. D. (2017). Maintenance Strategy for Public-Rented Residential Building: A Case Study in Jakarta, Indonesia. Build Environment Project and Asset Management, 7(1), 99-110.

Chew, M. Y., Tan, S. S., \& Kang, K. H. (2004). Building Maintanability-Review of State of the Art. Journal of Architectural Engineering, 10(3), 80-87.

Flores-Colen, I., Brito, J. d., \& Freitas, V. (2010). Discussion of Criteria for Prioritization of Predictive Maintenance of Building Facades - Survey of 30 Experts. Journal Performance of Constructed Facilities, 24(4), 337-344.

Kangwa, J., \& Olubodun, F. (2003). A Factor Approach to Analysis of Home Maintenance Outcomes and Attributes of Management Successes in the Owner-Occupied Sector. Structural Survey, 21(4), 158-172.

Kementerian Negara Perumahan Rakyat. (2007). Peraturan Menteri Negara Perumahan Rakyat Nomor 14/PERMEN/M/2007 tentang Pengelolaan Rumah Susun Sewa. Jakarta: Author.

Kementerian Negara Perumahan Rakyat. (2007). Peraturan Menteri Negara Perumahan Rakyat Nomor 18 Tahun 2007 tentang Petunjuk Pelaksanaan Perhitungan Tarif Sewa Rumah Susun Sederhana Sewa yang dibiayai oleh $A P B N$ dan $A P B D$. Jakarta: Author.

Menteri Hukum dan Hak Asasi Manusia. (2011). Undang-Undang Nomor 20 Tahun 2011 tentang Rumah Susun. In Lembaga Negara Republik Indonesia Tahun 2011 Nomor 5252. Jakarta: Author.

Mossel, H.-J. v., \& Jansen, S. J. (2010). Maintenance Services in Social Housing: What Do Residents Find Important. Structural Survey, 28(3), 215-229.

Oladapo, A. A. (2006). A Study of Tenants' Maintenance Awareness, Responsibility,and Satisfation in Institutional Housing in Nigeria. International Journal of Strategic Property Management, 10(4), 217-231.

Ozdemir, O. (2002). Reinvestment Decisions and Rehabilitation in Housing. In O. Ural, V. Abrantes \& A. Tadeu (Eds.). Housing Construction-an Interdisciplinary Task, 3, 1927-1934.

Pemerintah Kota Surabaya. (2012). Penghargaan. Retrieved 11 6, 2019, from https://surabaya.go.id/id/page/0/8230/penghargaan

Shen, Q., Lo, K., \& Wang, Q. (1998). Priority Setting in Maintenance Management: A Modified Multi- Attribute Approach Using Analytic Hierarchy Process. Construction Management and Economics, 16(6), 693-702.

Stewart, J. (2003). Home Maintenance: Initiatives in the Bellenden Renewal Area, Peckham. Journal of Enviromental Health Research, 2(1), 10-21.

Suffian, A. (2013). Some Common Maintenance Problems and Building Defects: Our Experiences. Procedia Engineering 54, 101-108.

Sugiyono. (2017). Metode Penelitian Kuantitatif, Kualitatif, dan $R \& D$. Bandung: Alfabeta, CV.

Usman, K., \& Winandi, R. (2009). Kajian Manajemen Pemeliharaan Gedung (Building Maintenance) di Universitas Lampung. Jurnal Sipil dan Perencanaan, 13(2), 157-166.

Wing, A. C., Mohammed, A. H., \& Abdullah, M. N. (2016a). Factors for Maintenance Priority in Malaysian University. Saint Humanika 8: 4-3, 1-5.

Wing, A. C., Mohammed, A. H., \& Abdullah, M. N. (2016b). A Literature Review on Maintenance Priority Conceptual Framework and Direction. MATEC Web of Conferences 66(00004), 1-7.

Yau, Y. (2011). Homeowners' Participation in Management of Multi-Storey Residential Buiildings: The Hong Kong's Case. Property Management, 29(4), 345-356.

Yusof, N. A., Abdullah, S., Zubedy, S., \& Najib, N. U. (2012). Resident' Maintenance Priorities Preference: The Case of Public Housing in Malaysia. Procedia - Sosial and Behavioral Sciences 62, 508-513. 